\title{
Evaluation of the Strength Properties of Asphalt Concrete using Natural Fibres as Reinforcing Additives
}

\author{
O. J. Oyedepo, E. O. Olukanni*, A. Alalade, A. Amoko, G. Oluwadare, O. Ayanda \\ Department of Civil Engineering, Federal University of Technology, Akure, Nigeria.
}

ABSTRACT: The period of maintenance and rehabilitation of asphalt concrete pavement can be increased by using fibres as reinforcement in a bituminous mix. Shredded Sisal fibre (Agave sisalana) and Sponge gourd (Luffa cylindrical) were used as reinforcements in bituminous mix. The fibres were added to hot mix asphalt in varying proportion of $0.1 \%, 0.2 \%, 0.3 \%, 0.4 \%$ and $0.5 \%$ by weight. The strength of fibre reinforced asphalt concrete was determined by conducting Marshall stability test. The tensile strength on 40 strands of fibre gave $167.43 \mathrm{~N} / \mathrm{mm}^{2}$ and $24.58 \mathrm{~N} / \mathrm{mm}^{2}$ for Sisal fibre and sponge gourd fibre respectively. Marshall Stability test results indicated that Sisal fibre gave minimum and maximum values of $4.46 \mathrm{kN}$ and $5.54 \mathrm{kN}$, respectively, which exceeded the $3.5 \mathrm{kN}$ minimum stability value for wearing course in the Nigerian General Specification for Roads and Bridges. The flow values obtained showed that the flow values are more than the $4 \mathrm{~mm}$ minimum value except for 0.1 sisal fibre dosage which has a value of $3.99 \mathrm{~mm}$. The high flow values obtained was an indication of the reinforcing effects of the fibres which made the asphalt concrete stronger and hence have great resistance to plastic deformation.

KEYWORDS: Strength properties, asphalt, fibre, reinforcement, marshall stability.

[Received Jun. 22, 2021; Revised Oct. 16, 2021; Accepted Oct. 24, 2021]

Print ISSN: 0189-9546 | Online ISSN: 2437-2110

\section{INTRODUCTION}

Asphalt is a material mostly used for road pavements and airport runways among others. It is a mixture of high-quality aggregates and mineral filler held together by a bituminous material. Hot Mix Asphalt is a combination of aggregates (coarse and fine) bound together by bitumen; its production process involves mixing of the aggregates with bitumen, placing and compacting at high temperature. Hot Mix Asphalt (HMA) can be categorized as dense graded mix also known as bituminous concrete or as gap graded known as stone matrix asphalt. Asphalt concrete, like Portland cement concrete, does not have adequate strength to withstand tensile stress but is strong in compression and this means that when subjected to tensile stresses that is more than the maximum tensile strength of the concrete, cracking may occur in the asphalt concrete. However, the performance of flexible pavement is highly dependent, to a great extent, on the quality and quantity of materials in appropriate proportion. Furthermore, the use non-renewable constituent materials in asphalt contributed immensely to the costs of construction, rehabilitation and maintenance of roads. Mohammad et al. (2018) affirmed that a good mix design of bituminous material will bring about a mix that is strong, durable, able to resist fatigue and deformation, environmentally friendly and economical. However, the aforementioned was achieved through different tests carried out on the mix with different proportions and finish with the best one. The mix design of the bituminous material must achieve correct percentage of bitumen to be sure of the a durability of pavement, good resistance to shear deformation when exposed to traffic at a very high temperature, air voids in the bitumen (compacted) sufficient enough to make further compaction by traffic possible, workability to allow placement of the bituminous mix without segregation, good resistance to prevent cracking due to continuous bending by axle loads generated by traffic and resistance at low temperature capable of preventing shrinkage cracks.

Many researchers have explored the use of alternative materials that are renewable and use of industrial wastes (to reduce environmental pollution), which will increase the strength and performance of the asphalt concrete when used as a stabilizing additive. Industries that are involved in the production of bitumen are exploring ways to achieve sustainable means to achieve modifications and alternative ways to improve the performance of the bituminous road pavements and reduce its carbon footprint (Fereidoon et al., 2014).

In general, fibres and polymers have been extensively used to reinforce asphalt concrete and it has shown great assurances (Abtahi et al., 2010, Rahnama, 2009). Fibres are small and short reinforcing material that are produced from different materials like plastic, glass, carbon, and natural materials that can be found in various shapes and sizes. Natural fibres are produced by plants like wood, vegetables leaves and animals. Many researchers have made use of fibres obtained from plant as alternatives to steel and other synthetic 
fibres being used in composites like concrete, mortar and cement paste to boost the strength properties (Ali, 2012).

Sisal fibre is one of the natural fibers that has performed excellently over the years. It possesses many properties like high tensile strength, low cost and high durability (Aruna, 2014). More so, Sisal fibre is readily available, cheap and renewable. For concrete pavement applications, fibre reinforced concrete can be utilized in new concrete pavement construction, maintenance like patching, rehabilitation such as overlays and total pavement reconstruction. Also, macrofibres which are very fine and made from synthetic materials have been introduced to continuously reinforce concrete pavement mixtures (Folliard et al., 2006; Dahal et al., 2019).

The benefit of macrofibres in fresh and hardened properties of concrete pavements has been corroborated through laboratory research (LaHucik et al., 2017). Equally, fibres can also be introduced into pavement to make the bitumen more stable and to prevent the segregation of binder from the aggregate during transportation and placement. Saranya et al. (2018) stated that fibres are important types of reinforcements that are capable of transferring strength to the matrix constituent while also enhancing their properties.

Okeola et al. (2018) evaluated the mechanical and physical properties of concrete reinforced with Sisal fibre, the fibres were introduced into the mix at percentages range of $0.5 \%$ to $2.0 \%$ by weight of cement in $0.5 \%$ increments. Physical properties of the fibres such as water absorption, workability, and density were measured. Mechanical properties were also investigated, they were split tensile strength, static modulus of elasticity and compression strength. The research findings showed that that Sisal fibre has the capability to improve the Young's modulus of concrete and split tensile strength but unable to show a significant improvement on its workability, compressive strength and water absorption. Palit et al. (2004) investigated the use of crumb rubber which were obtained from waste tyre using an 80/100 grade of bitumen in stone matrix asphalt; the research showed that crumb tyre has significant improvement on the fatigue and permanent deformation properties of the asphalt concrete and greater moisture damage resistance than normal mixes.

Additionally, Hassan et al. (2011) studied the effect of the introduction of waste glass powder as mineral filler in the production of asphalt concrete on the Marshall property of stone matrix asphalt where limestone and ordinary Portland cement were used as filler with varying content (4-7\%) and compared with stone matrix asphalt with glass as fillers. The optimum value of glass powder content was found to be $7 \%$. The researchers concluded that the use of glass powder as a filler in stone matrix asphalt increased the stability up to $13 \%$. There is also a reduction in flow value up to $39 \%$, density value also decreased relative to stone matrix asphalt that contains limestone and cement filler.

Karahancer et al. (2019) affirmed that fibres can be added into open-graded mixtures or porous asphalt to avoid drain down of bitumen from aggregates. Naveen (2016) investigated the drain down property of mixtures of stone matrix asphalt produced with conventional 60/70 penetration grade bitumen using Sisal fibre as additives. Findings from the research indicated that $0.28 \%$ addition of Sisal fibre only significantly improved the Marshall properties of stone matrix asphalt mixes. The drain down characteristics of the stone matrix of mixes with conventional bitumen improved significantly on the addition of $0.28 \%$ fibre; therefore, it satisfies the prescribed specifications. Likewise, the tensile properties of Sisal nanofibre reinforced polymer composites were compared with glass fibre reinforced polymer composites. The experimental results indicated that the tensile strength of Sisal nanofibre reinforced polymer composites showed high strength relative to glass fibre reinforced polymer composites. Naidu et al. (2011) studied the compressive and impact properties of Sisal/Glass fibre reinforced hybrid composites. It was concluded that the impact and compressive strengths of Sisal/glass fibre hybrid component is more than that of Sisal/fibre reinforced composite, but less than that of glassreinforced composite.

Oriola et al. (2019) added 1\% of Sisal fibre by weight of dry constituents to examine the shear strength characteristics of Sisal Fibre Reinforced Concrete (SSFRC). The addition of Sisal fibre increased the compressive strength of the concrete by an average of $16.9 \%$ and the shear strength by $16 \%$. In the same vein, the effects of the usage of a Sisal fibre as a stabilizer in stone matrix asphalt and as an additive in bituminous concrete was investigated by Mohammad et al. (2018), the fibre content was varied from $0 \%$ to $0.5 \%$ of the total mix. The optimum fibre content for both asphalt concrete and stone matrix asphalt mixes was found to be $0.3 \%$. Besides, the optimum binder content for bituminous concrete and stone matrix asphalt was found to be 5 and $5.2 \%$ respectively. They concluded that the introduction of Sisal fibre improved the mix properties like drain down characteristics, indirect tensile strength and Marshall stability for both bituminous concrete and stone matrix asphalt. This research focuses on the evaluation of the strength properties of asphalt concrete using natural fibre as a stabilizing additive.

\section{MATERIALS AND METHODS}

\section{A. Materials}

The bitumen used for this research was a 60/70 penetration grade obtained from KK Hassan Limited, Owo road, Akure, Nigeria. The aggregate of sizes 5 to $8 \mathrm{~mm}$ used was sourced from a quarry in Aaye town, Ondo State in Nigeria. Also, river sand free from deleterious materials were sourced from Ala river in Akure. Two shredded natural fibres namely Sisal fibre (Agave Sisalana) and Sponge gourd or Loofah plant (Luffa Cylindrical) were used as stabilizing additives in this research. The fibres were sourced from Arakale market and Oja Oba market in Akure Ondo State of Nigeria.

Sisal fibre is a natural fibre of Agave cease family, it yields a stiff fibre traditionally which is used in making twine and rope. It has cream to off white colour, 80 to $120 \mathrm{~cm}$ in length and 0.2 to $0.4 \mathrm{~mm}$ in diameter and contains many strands as shown in Figure 1. The sponge gourd (Luffa Cylindrical) is a fibrous plant with fruits containing black seeds. It grows as a flowering annual vine with pollinated flowers in cylindrical green fruits with a lot of seed in intertwined cellulose fibres. Figure 2 is a sample of the sponge gourd. 

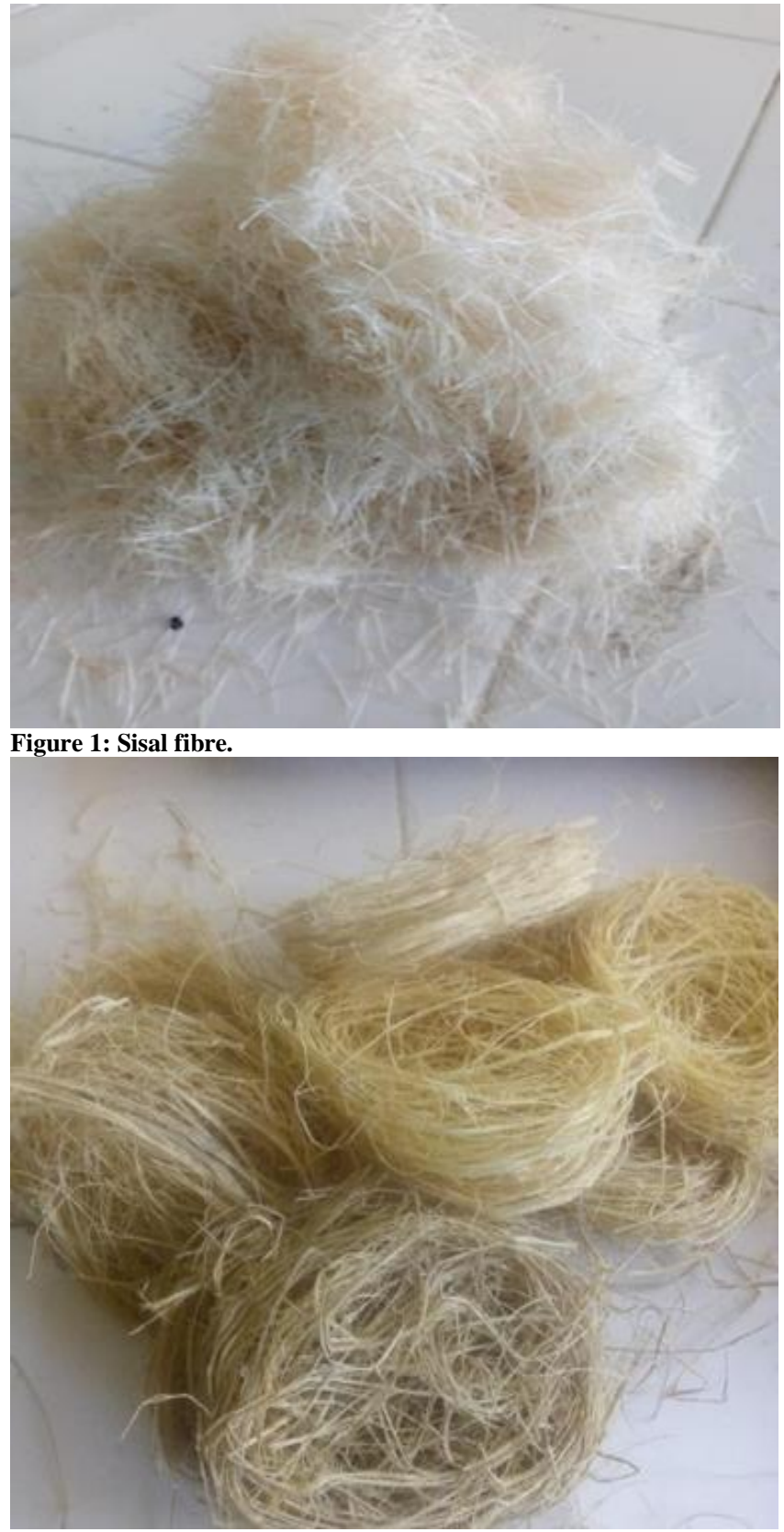

Figure 2: Sponge gourd fibre.

\section{B. Sample Preparation}

Both the conventional asphalt concrete and fibre reinforced asphalt concrete were produced by thoroughly mixing the materials for 25 minutes at a temperature range of 100 to $120{ }^{\circ} \mathrm{C}$. For the asphalt production, $58 \%$ of fine aggregate, $37 \%$ coarse aggregate and 5\% (60 g) of mineral filler was used for the mix. Three different percentages of bitumen i.e., 5.5, 6.0 and $6.5 \%$ of the total mass of the aggregate were used out of which the optimum bitumen content was determined. Also, the fibres were added separately in percentages of $0.1,0.2,0.3,0.4$ and $0.5 \%$ by weight of the total aggregate. The asphalt concrete samples were properly compacted with $4.5 \mathrm{~kg}$ rammer in the cylindrical mould with 50-75 blows as indicated in Figure 3. The compacted sample was removed from the mould with sample extruder in Figure 4.
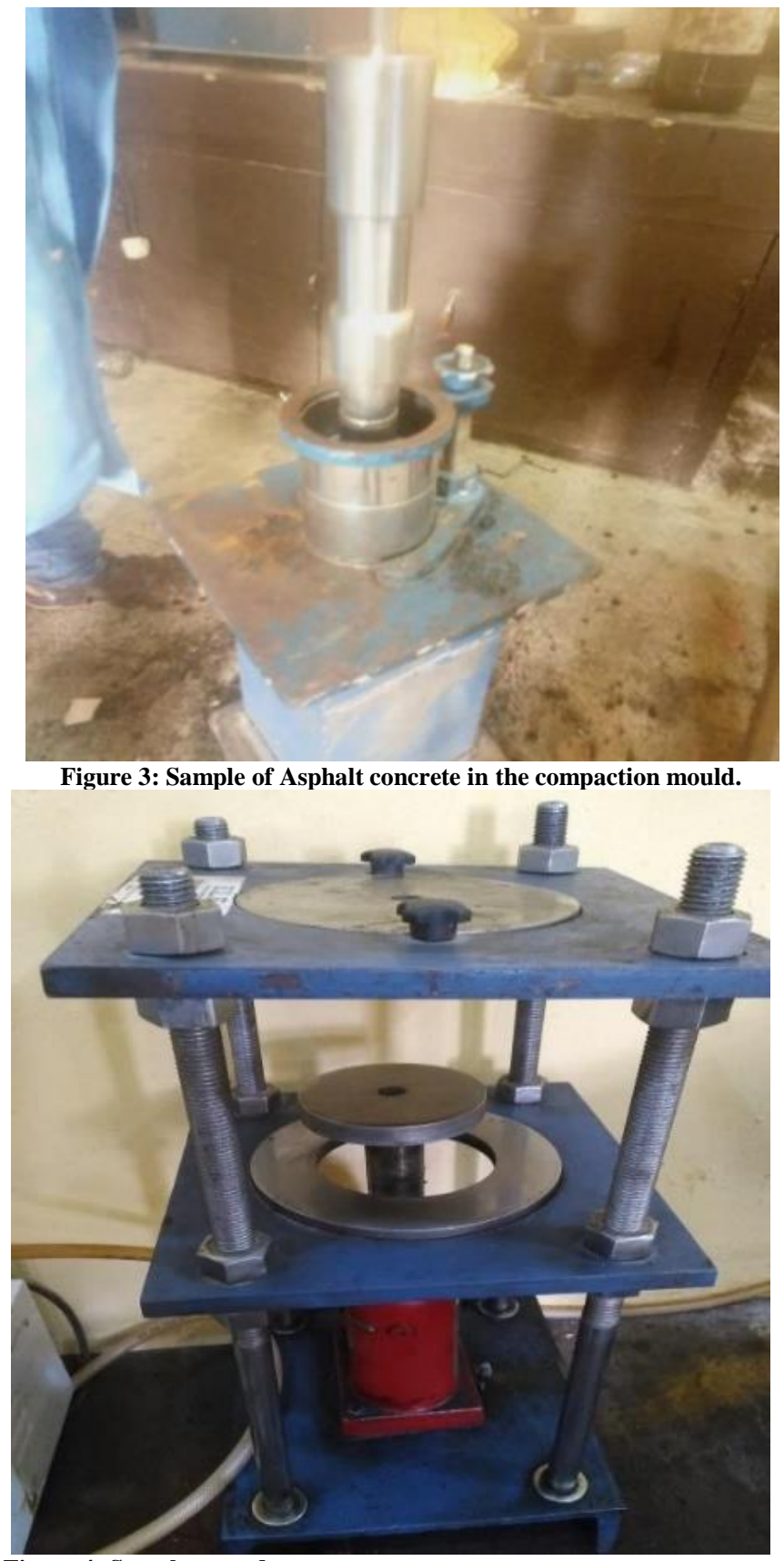

Figure 4: Sample extruder.

\section{Method}

Tests were performed to relative standards on aggregates, bitumen, fibre and asphalt concrete used in this research. Aggregate Impact Value (AIV) test (BS 812-112, 1990), Aggregate Crushing Value (ACV) test (BS 812-110, 1990) and Specific Gravity test (ASTM C128-15) were performed to determine the properties coarse aggregate. Particle Size Analysis test (BS 812-103, 1990) and Moisture Content test (ASTM C566-19) were performed on fine aggregates. Penetration test (ASTM D5-95), Flash and Fire Point test (ASTM D92-90) and Water-in-Bitumen test (ASTM D95) were performed on bitumen to determine its properties. Tensile Strength test (ASTM E8 / E8M - 21) was carried out on natural fibres to determine their tensile strengths while Marshall Stability test (ASTM D6927-15) was performed on 
asphalt concrete and fibre reinforced asphalt concrete.

\section{RESULTS AND DISCUSSION}

\section{A. Tensile Test of Fibre}

The tensile strength test result on the natural fibres used in this research is presented in Table 1. The tensile strength of the fibres was tested on different strands of each fibre. The strands tested are were 1, 20 and 40 strands.

Table 1: Tensile Strength Tests on the Fibres

\begin{tabular}{ccc}
\hline Fibre Strands & Sisal Fibre $\left(\mathbf{N} / \mathbf{m m}^{2}\right)$ & $\begin{array}{c}\text { Sponge Gourd } \\
\left(\mathbf{N} / \mathbf{m m}^{2}\right)\end{array}$ \\
\hline 40 & 167.43 & 24.58 \\
20 & 41.93 & 15.51 \\
1 & 38.76 & 9.98 \\
\hline
\end{tabular}

The graphical representation of the tensile strength of fibres is presented in Figures 5 to 7 . The ultimate tensile strength obtained using 40 strands gave values of 167.43 and $24.58 \mathrm{~N} / \mathrm{mm} 2$ for Sisal fibre and sponge gourd respectively. This implies that Sisal fibre performed better in strength than Sponge gourd when used as additives in asphalt concrete. However, the tensile strength increased with an increase in the number of strands.

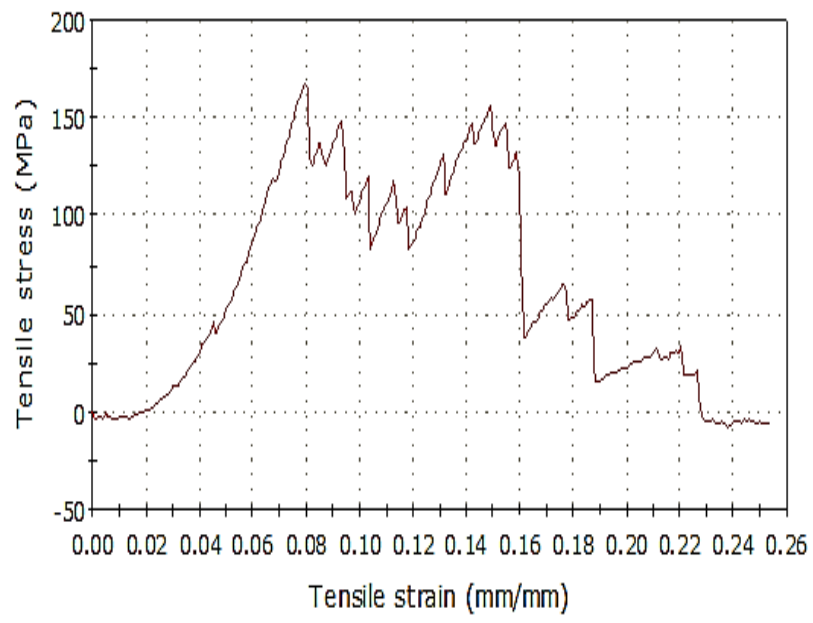

(a)

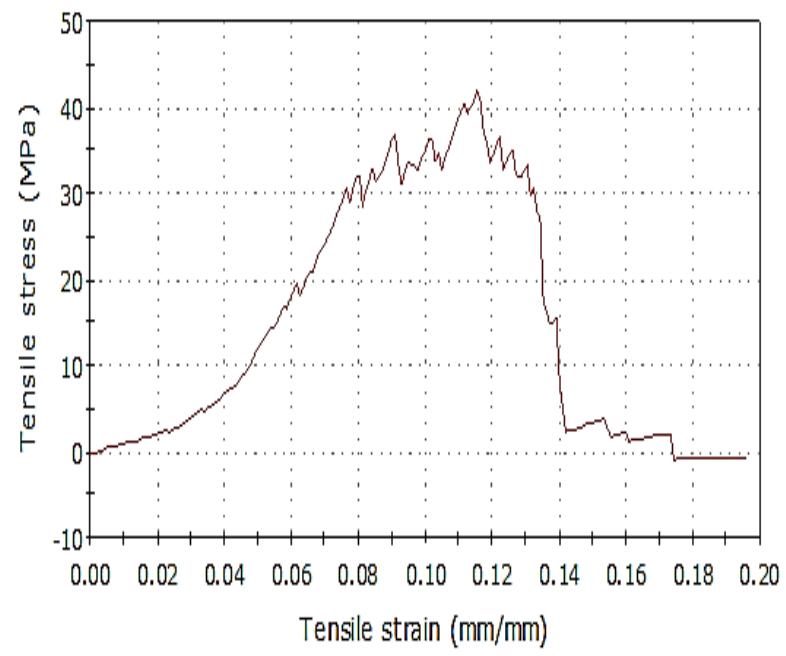

(b)

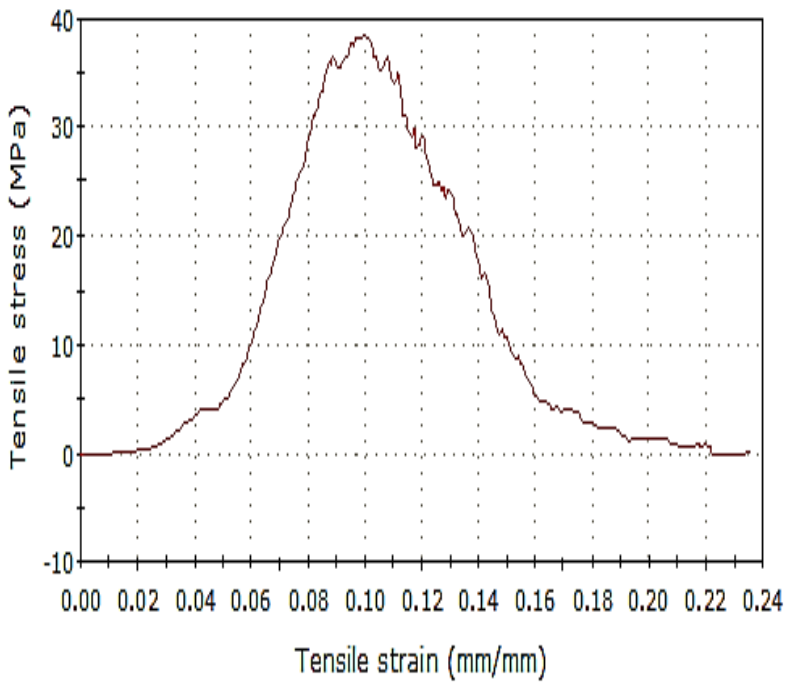

(c)

Figure 5: Ultimate Tensile Strength of Sisal Fibre. (a) Ultimate Tensile Strength of 40 strands of Sisal fibre.(b) Ultimate Tensile Strength of 20 strands of Sisal fibre. (c) Ultimate Tensile Strength of 10 strands of Sisal fibre.

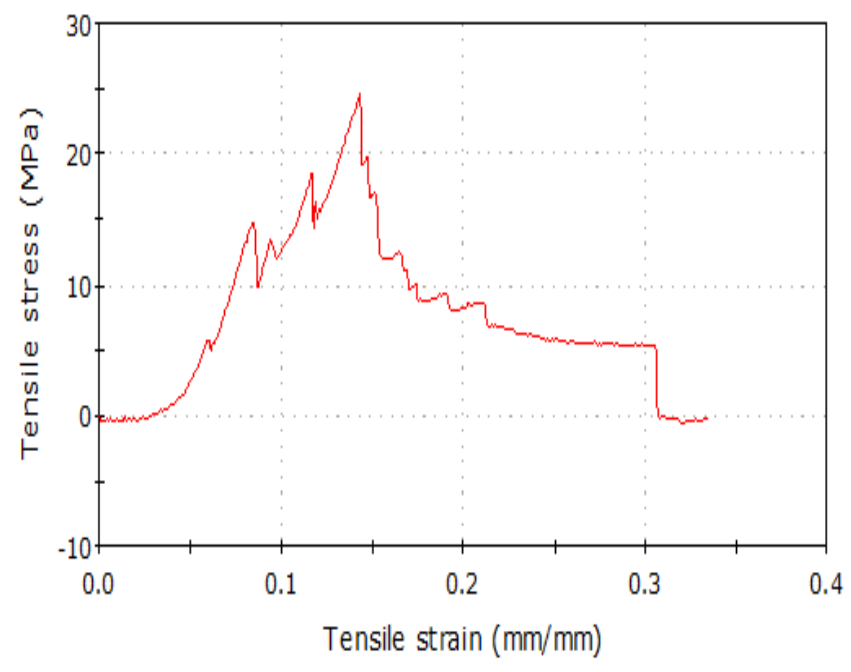

(a)

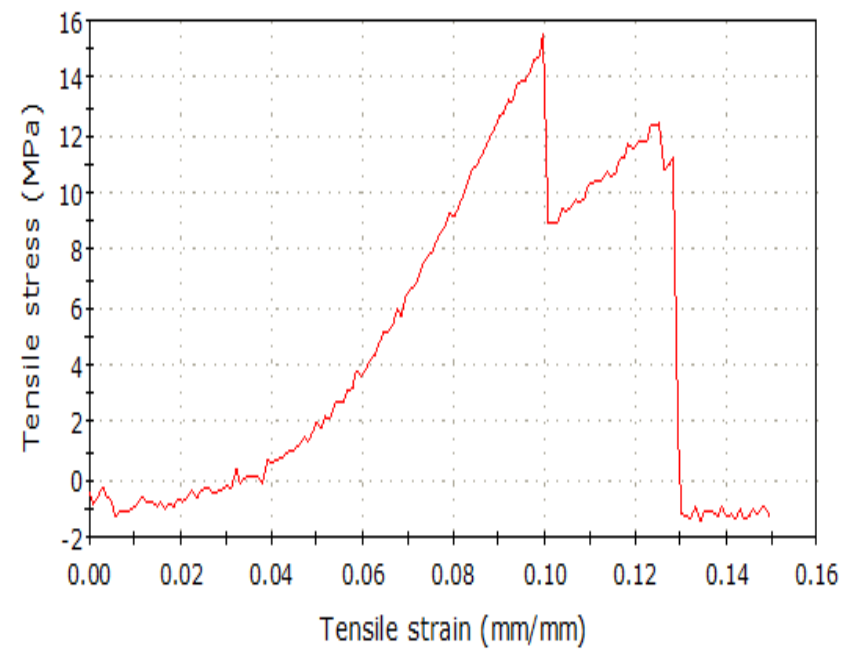

(b) 


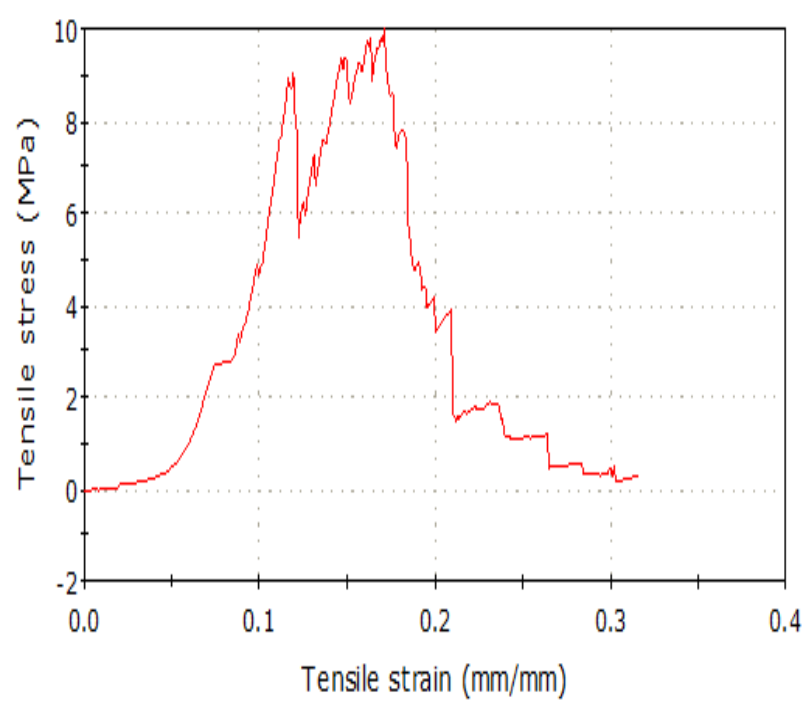

(c)

Figure 6: Ultimate Tensile Strength of Sponge Gourd (a) Ultimate Tensile Strength of 40 Strands of Sponge Gourd (b) Ultimate Tensile Strength of 20 Strands of Sponge Gourd (c) Ultimate Tensile Strength of 10 Strands of Sponge Gourd.

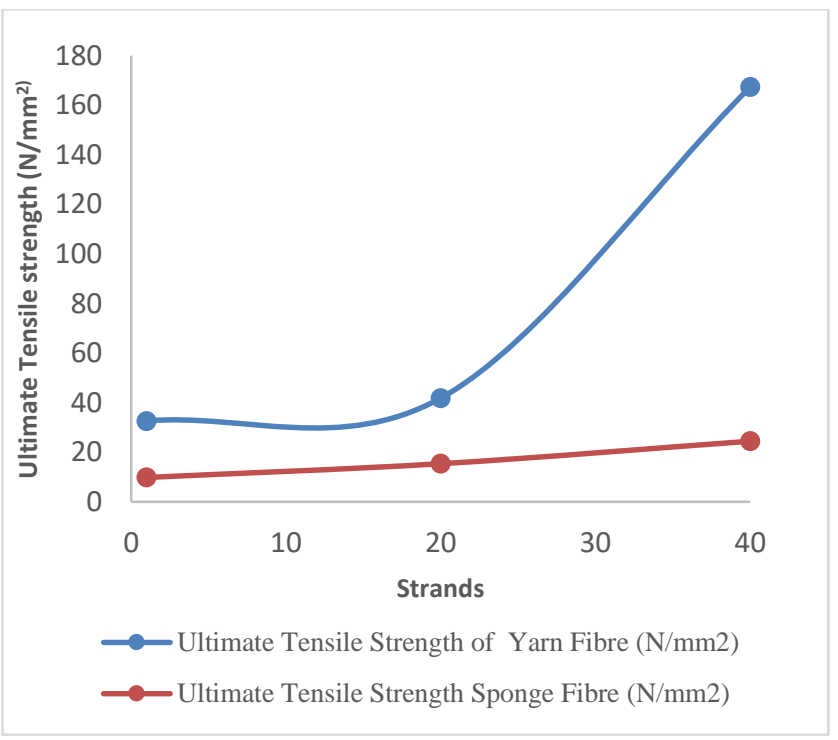

Figure 7: Ultimate Tensile Strength of Sisal Fibre and Sponge Gourd.

B. Aggregate Impact Value Test (AIV)

Result obtained from the aggregate impact value (AIV) test conducted to determine the resistance of the aggregates used against impact load is in Table 2.

Table 2: Coarse Aggregate Impact Value.

\begin{tabular}{lccc}
\hline & Sample 1 & Sample 2 & Sample 3 \\
\hline Initial Weight (g) & 400 & 400 & 400 \\
Final Weight (g) & 95.6 & 94.9 & 95.01 \\
AIV (\%) & 23.9 & 23.72 & 23.75 \\
\hline
\end{tabular}

The average AIV obtained is $23.79 \%$, this is an indication that the aggregates used has good strength to withstand impact load when used for asphalt concrete production.

\section{Aggregate Crushing Value (ACV)}

The ACV test performed to determine the resistance of aggregate used against gradually applied crushing load is presented in Table 3.

Table 3: Coarse Aggregate Crushing Value.

\begin{tabular}{lccc} 
& Sample 1 & Sample 2 & Sample 3 \\
\hline Initial Weight (g) & 500 & 500 & 500 \\
Final Weight (g) & 142.2 & 143.7 & 145.4 \\
ACV (\%) & 28.44 & 28.74 & 29.08 \\
\hline
\end{tabular}

The average ACV obtained is $28.62 \%$ which is not up to the maximum permissible value of $40 \%$ for bituminous macadam.

\section{Particle Size Distribution}

The result of the distribution of sizes of aggregates used for the preparation of asphalt concrete in this research is shown in Figure 8.

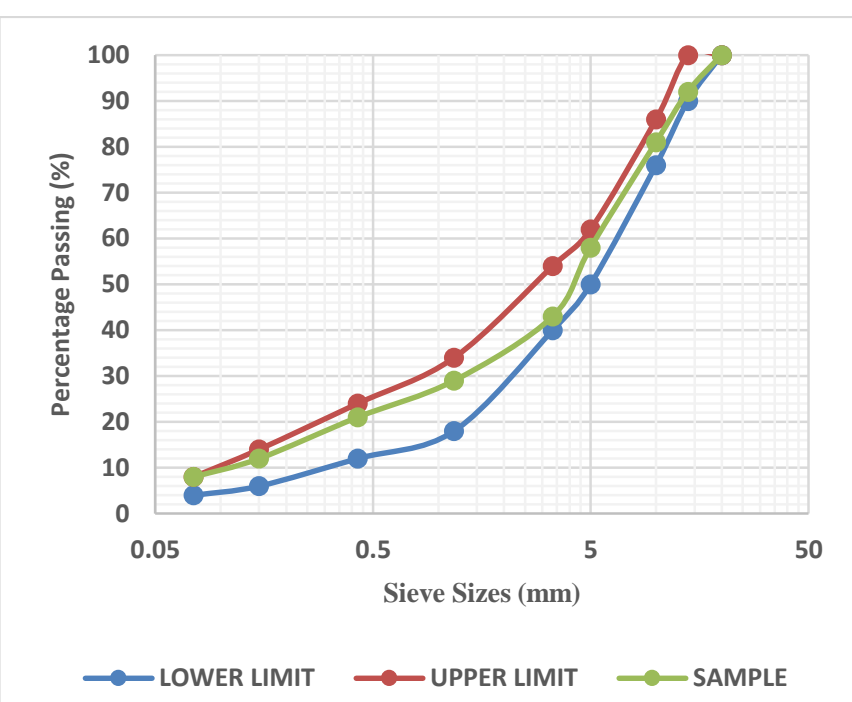

Figure 8: The graphical representation of the particle size distribution.

The graph of particle size distribution curve in Figure 8 indicated that the particles is within the specified upper and lower limits. This confirms that the aggregate grading requirement for asphalt concrete production has been satisfied by the aggregates.

\section{E. Moisture Content Test}

The moisture content of the fine aggregate used was determined to evaluate its conformity with the standard requirement for their use in asphalt concrete. The moisture content is contained in Table 4. Average moisture content $(\mathrm{AMC})$ is given in Eq. (1).

$$
A M C=\frac{M C 1+M C 2+M C 3}{3}
$$

where:

$M C_{1}$ is the moisture content of Sample $1, M C_{2}$ is the moisture content of Sample $2 M C_{3}$ is the moisture content of 
Sample 3. The average moisture content obtained for the aggregates used is $1.66 \%$ which is less than the maximum permissible moisture content of 5\%. Therefore, the material meets the moisture content requirement for asphalt concrete production.

Table 4: Moisture content of fine aggregate.

\begin{tabular}{lccc}
\hline Can No. & Sample 1 & Sample 2 & Sample 3 \\
\hline Weight of Can & 25.5 & 25.6 & 23.1 \\
Weight of Can + Sample & 175.5 & 130.5 & 141 \\
Weight of Can + Dry & 172.84 & & 138.9 \\
Sample & & 128.42 & \\
Weight of Moisture & 2.66 & 2.08 & 2.10 \\
Weight of Dry Sample & 147.34 & 102.82 & 115.8 \\
Moisture Content (\%) & 1.77 & 1.39 & 1.81 \\
\hline
\end{tabular}

\section{F. Specific Gravity Test}

The specific gravity test was performed on aggregates and bitumen used to investigate the weight to volume relationships and to calculate quantities that are related to volume such as voids in mineral aggregate (VMA) and voids filled by bitumen (VFB). The specific gravity of the materials used is presented in Table 5.

Table 5: Specific gravity of materials used.

\begin{tabular}{lc}
\hline Material & Specific Gravity \\
\hline Coarse Aggregate & 2.50 \\
Fine Aggregate & 2.66 \\
Mineral Filler & 2.69 \\
Bitumen & 1.03 \\
\hline
\end{tabular}

\section{G. Penetration Test}

This test is performed on the bitumen to determine its grade and consistency. The results obtained for the test conducted is in Table 6.

Table 6: Penetration test.

\begin{tabular}{lccc}
\hline & Sample 1 & Sample 2 & Sample 3 \\
\cline { 2 - 4 } Final Penetration (dmm) & 64.20 & 63.90 & 64.00 \\
Initial Penetration & 0.00 & 0.00 & 0.00 \\
$(\mathrm{dmm})$ & 64.20 & 63.90 & 64.00 \\
\hline
\end{tabular}

The average penetration value obtained is $64.03 \mathrm{dmm}$ (decimillimetre), this confirms that the bitumen is a $60 / 70$ penetration grade bitumen according to the standard specification for penetration-graded asphalt cement for use in pavement construction (ASTM D946 / D946M - 20) and the Nigerian General Specification for Roads and Bridges of the Federal Ministry of Works (1997) which is adjudged the best grade of bitumen for road construction in the tropical region like Nigeria.

\section{H. Flash and Fire Point Tests}

The test is performed to measure the temperature at which a bituminous material will give a flash of fire and flash when subjected to an incremental temperature. The result is presented in Table 7.
Table 7: Flash and fire point.

\begin{tabular}{lcccccc}
\hline & \multicolumn{2}{c}{ Sample 1 } & \multicolumn{2}{c}{ Sample 2 } & \multicolumn{2}{c}{ Sample 3 } \\
\cline { 2 - 7 } & $\begin{array}{c}\text { Flash } \\
\text { Point }\end{array}$ & $\begin{array}{c}\text { Fire } \\
\text { Point }\end{array}$ & $\begin{array}{c}\text { Flash } \\
\text { Point }\end{array}$ & $\begin{array}{c}\text { Fire } \\
\text { Point }\end{array}$ & $\begin{array}{c}\text { Flash } \\
\text { Point }\end{array}$ & $\begin{array}{c}\text { Fire } \\
\text { Point }\end{array}$ \\
\hline $\begin{array}{l}\text { Initial Temperature } \\
\left({ }^{\circ} \mathrm{C}\right)\end{array}$ & 0 & 0 & 0 & 0 & 0 & 0 \\
$\begin{array}{l}\text { Final Temperature } \\
\left({ }^{\circ} \mathrm{C}\right)\end{array}$ & 235 & 298 & 240 & 290 & 239 & 295 \\
Temperature $\left({ }^{\circ} \mathrm{C}\right)$ & 235 & 298 & 240 & 290 & 239 & 295 \\
\hline
\end{tabular}

The average flash point obtained is $238 \mathrm{OC}$ and the average fire point obtained is $2940 \mathrm{C}$ and these are within the specified limit in the standard specification for penetrationgraded asphalt cement for use in pavement construction (ASTM D946/D946M) and the Nigerian General Specification for Roads and Bridges of the Federal Ministry of Works (1997).

\section{Water-In-Bitumen Test}

The result of the water-in-bitumen test performed on the bitumen used in this research in Table 8 showed that the average water in the bitumen used was $3.7 \%$ which was less than the 5\% maximum permissible limit in the standard specification for penetration-graded asphalt cement for use in pavement construction (ASTM D946/D946M) and the Nigerian General Specification for Roads and Bridges of the Federal Ministry of Works (1997).

Table 8: Water-in-Bitumen.

\begin{tabular}{|c|c|c|c|}
\hline & Sample1 & Samplen2 & Sample 3 \\
\hline Weight of sample (g) & 50 & 50 & 50 \\
\hline $\begin{array}{l}\text { Weight of water in } \\
\text { condenser }(g)\end{array}$ & 1.75 & 1.98 & 1.86 \\
\hline $\begin{array}{l}\text { Percentage of water-in- } \\
\text { bitumen }(\%)\end{array}$ & 3.5 & 3.9 & 3.7 \\
\hline
\end{tabular}

\section{J. Softening Point Test}

The result of the softening point test conducted on three samples of bitumen is presented in Table 9. From the table, it is shown that the average softening point calculated was within the $45{ }^{\circ} \mathrm{C}$ minimum requirement for the grade of bitumen to be used in asphalt concrete. This is based on the standard specification for penetration-graded asphalt cement for use in pavement construction (ASTM D946/D946M) and the Nigerian General Specification for Roads and Bridges of the Federal Ministry of Works (1997).

Table 9: Softening test.

\begin{tabular}{lccc}
\hline & Sample 1 & Sample 2 & Sample 3 \\
\cline { 2 - 4 } Softening Temperature $\left({ }^{\circ} \mathrm{C}\right)$ & 50.2 & 48.8 & 49.6 \\
\hline
\end{tabular}

\section{K. Ductility Test}

The ductility of bituminous material measures the length to which bituminous material will extend before it breaks. The result obtained from the ductility test conducted on the bitumen used is in Table 10.

Table 10: Ductility test.

\begin{tabular}{lccc}
\hline & Sample 1 & Sample 2 & Sample 3 \\
\hline Ductility $(\mathrm{cm})$ & 103 & 103 & 102 \\
\hline
\end{tabular}


The result of the test showed that the average ductility of the bitumen used $103 \mathrm{~cm}$; the value obtained is greater than the recommended minimum value of $100 \mathrm{~cm}$ in the standard specification for penetration-graded asphalt cement for use in pavement construction (ASTM D946/D946M) and the Nigerian General Specification for Roads and Bridges of the Federal Ministry of Works. Hence, the bitumen is suitable for use.

\section{Marshall Stability of Asphalt Concrete}

The Marshall stability test to determine the resistance to flow and deformation of the asphalt concrete sample was carried out on the samples produced with different dosage of the fibres. The result of the volume and density properties of the Marshall samples is presented in Table 11.

Table 11: Volume and density properties of the marshall samples

\begin{tabular}{|c|c|c|c|c|c|}
\hline $\begin{array}{c}\text { Bitumen } \\
\text { Content } \\
(\%)\end{array}$ & $\begin{array}{c}\text { Unit } \\
\text { Weight } \\
\text { Kg/cm }\end{array}$ & $\begin{array}{c}\text { VMA } \\
(\%)\end{array}$ & $\begin{array}{l}\text { VFB } \\
(\%)\end{array}$ & $\begin{array}{c}\text { Stability } \\
(\mathbf{k N})\end{array}$ & $\begin{array}{l}\text { Flow } \\
(\mathrm{mm})\end{array}$ \\
\hline 5.5 & 2.36 & 6.51 & 59.14 & 4.22 & 5.98 \\
\hline 6.0 & 2.37 & 4.26 & 67.40 & 4.78 & 6.35 \\
\hline 6.5 & 2.36 & 4.26 & 77.80 & 4.56 & 6.03 \\
\hline
\end{tabular}

The graphical representation of these properties is presented in Figures 9 -12.

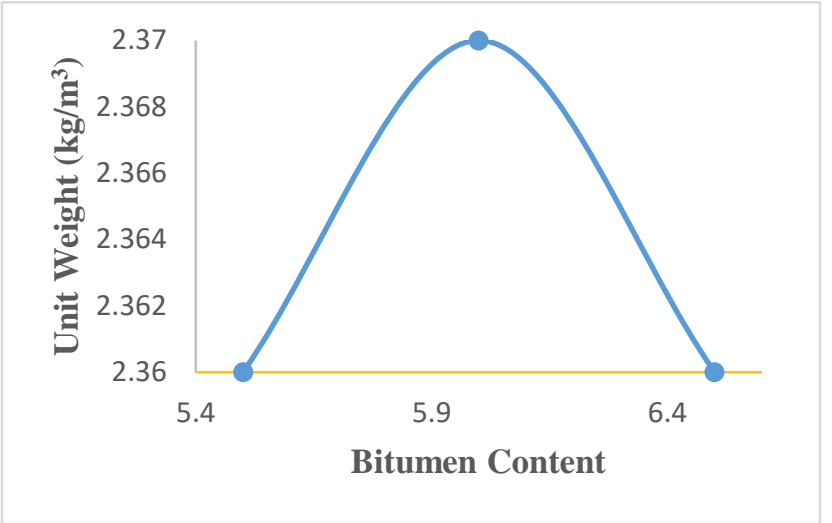

Figure 9: Variation of unit weights for different bitumen contents.

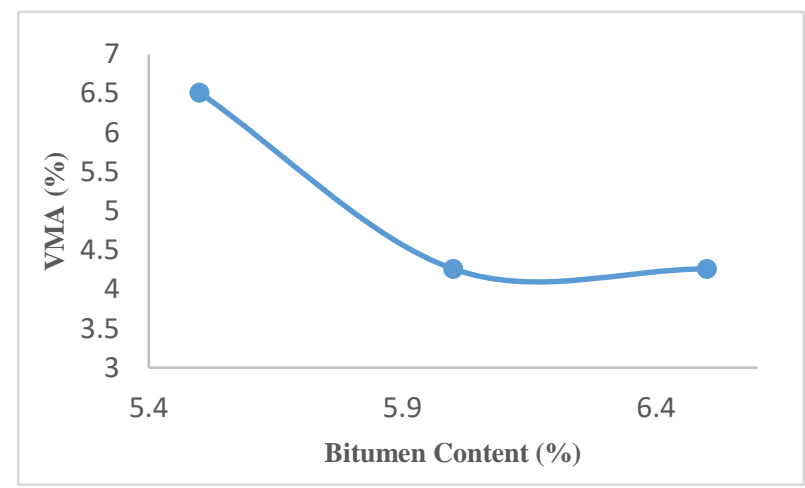

Figure10: Variation of VMA for different bitumen contents.

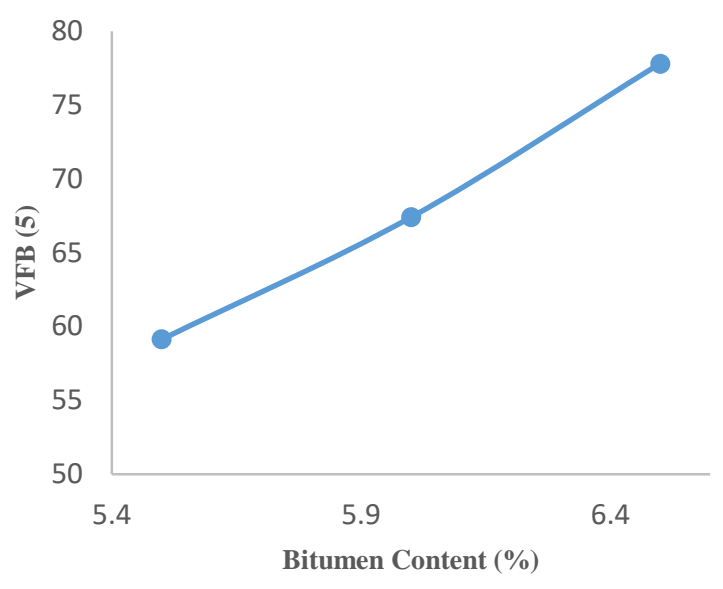

Figure 11: Variation of VFB for different bitumen contents.

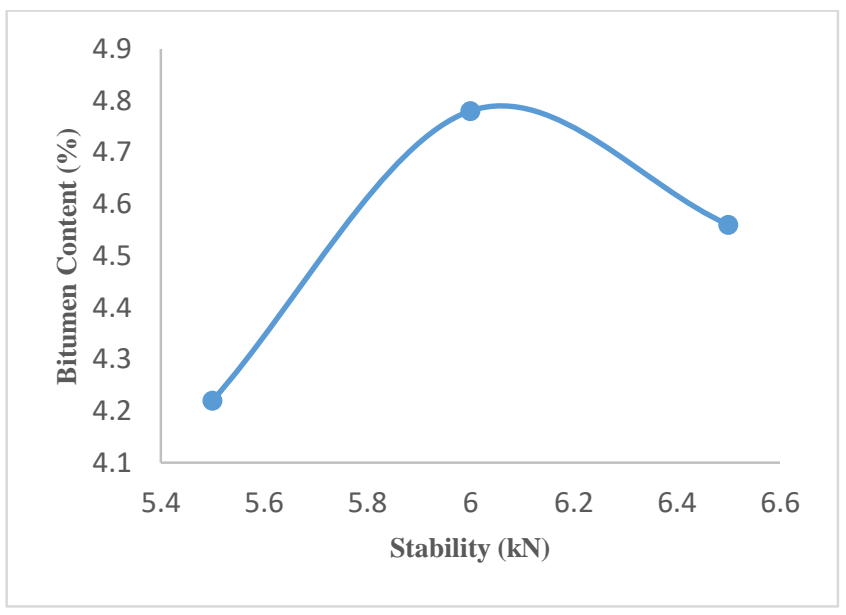

Figure 12: Variation of Stability for different bitumen contents.

The density and volume properties of the Marshall samples revealed that $6 \%$ bitumen content has the highest percentage content and therefore, it is selected as the optimum bitumen content used for all the fibre dosages. The result of Marshall Stability of the asphalt concrete samples produced with different fibre dosages and $6 \%$ bitumen content is presented in Tables 12.

Table 12: Marshall stability of Sisal fibre and sponge gourd.

\begin{tabular}{ccccccc}
\hline \multirow{2}{*}{$\begin{array}{c}\text { Fibre } \\
\text { Dosage } \\
(\%)\end{array}$} & $\begin{array}{c}\text { Average } \\
\text { Dial } \\
\text { Reading } \\
(\mathbf{m m})\end{array}$ & $\begin{array}{c}\text { Load } \\
(\mathbf{k g})\end{array}$ & $\begin{array}{c}\text { Stability } \\
(\mathbf{k N})\end{array}$ & $\begin{array}{c}\text { Average } \\
\text { Dial } \\
\text { Reading } \\
(\mathbf{m m})\end{array}$ & $\begin{array}{c}\text { Load } \\
(\mathbf{k g})\end{array}$ & $\begin{array}{c}\text { Stability } \\
(\mathbf{k N})\end{array}$ \\
\hline 0.1 & 626.00 & 538.03 & 5.38 & 622.67 & 535.17 & 5.35 \\
0.2 & 644.00 & 553.67 & 5.54 & 697.00 & 599.24 & 5.99 \\
0.3 & 619.00 & 532.34 & 5.32 & 561.00 & 482.46 & 4.82 \\
0.4 & 519.00 & 446.34 & 4.46 & 527.33 & 453.50 & 4.54 \\
0.5 & 611.00 & 525.46 & 5.25 & 527.33 & 453.50 & 4.54 \\
\hline
\end{tabular}

The Marshall Stability test carried out on the sample produced with Sisal Fibre returned results of stability values that ranged between $4.46 \mathrm{kN}$ and $5.54 \mathrm{kN}$, these values exceed the $3.5 \mathrm{kN}$ which is the expected stability value for wearing course in the Nigerian General Specification for Roads and 
Bridges of the Federal Ministry of Works and the specifications of the Asphalt Institute in Table 13.

Table 13: The asphalt institute typical marshall design criteria.

\begin{tabular}{|c|c|c|c|c|c|}
\hline \multirow[t]{2}{*}{ Mix Criteria } & \multicolumn{2}{|c|}{$\begin{array}{l}\text { Light Traffic } \\
\left(<10^{4} \text { ESALs }\right)\end{array}$} & \multicolumn{2}{|c|}{$\begin{array}{c}\text { Medium } \\
\text { Traffic } \\
\left(10^{4}-10^{6}\right. \\
\text { ESALs })\end{array}$} & $\begin{array}{c}\text { Heavy } \\
\text { Traffic } \\
\left(>10^{6}\right. \\
\text { ESALs }) \\
\end{array}$ \\
\hline & Min. & Max. & Min. & Max. & Min. Max. \\
\hline
\end{tabular}

Compaction

(number of blows

on each end of the

sample)

Stability (minimum)

(N)

\begin{tabular}{lccccc}
35 & - & 50 & - & 75 & - \\
2224 & - & 3336 & - & 6672 & - \\
8 & 20 & 8 & 18 & 8 & 16 \\
3 & 5 & 3 & 5 & 3 & 5 \\
\hline
\end{tabular}

The results obtained showed an increasing trend in the stability values obtained, which resulted from the fibres used which serve as reinforcement for the asphalt concrete. It is also noteworthy that the comparative consideration of the stability values obtained showed that Sisal fibre reinforced asphalt concrete displayed higher stability values. The highest stability value of $5.54 \mathrm{kN}$ was obtained for Sisal fibre reinforced asphalt concrete was obtained at $0.2 \%$ fibre dosage while the highest stability of $5.99 \mathrm{kN}$ for sponge gourd reinforcement was obtained at $0.2 \%$ fibre dosage. The graphical representation of the stability values of each fibre reinforced asphalt is presented in Figure 13.

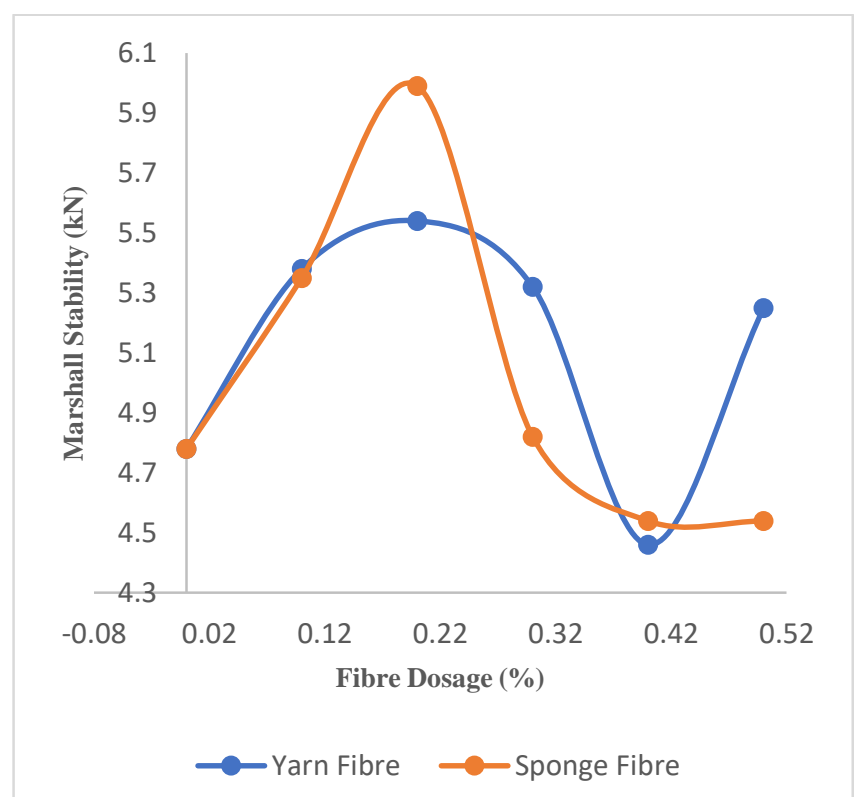

Figure 13: Distribution of marshall stability with different Sisal fibre and sponge gourd dosage.

The corresponding flow value of the mix is found to have a substantial increase with the increase in fibre content as shown in Table 14. The Nigerian General Specification for Roads and Bridges of the Federal Ministry of Works specified that the flow value for wearing course should range between $2-4 \mathrm{~mm}$, however, the values obtained showed that the flow values are more than the $4 \mathrm{~mm}$ maximum value except for 0.1 Sisal fibre dosage which has a value of $3.49 \mathrm{~mm}$; the flow values obtained also satisfies the requirement of the Asphalt Institute in Table 13.

Table 14: Flow of Sisal fibre and sponge gourd

\begin{tabular}{ccccccc}
\hline & \multicolumn{3}{c}{ Sisal Fibre } & \multicolumn{3}{c}{ Sponge Gourd } \\
\cline { 2 - 7 } $\begin{array}{c}\text { Fibre } \\
\text { Dosage } \\
(\%)\end{array}$ & $\begin{array}{c}\text { Average } \\
\text { Dial } \\
\text { Reading }\end{array}$ & $\begin{array}{c}\text { Flow } \\
\text { Value } \\
(\mathbf{m m})\end{array}$ & $\begin{array}{c}\text { Corrected } \\
\text { Flow } \\
\text { Value } \\
(\mathbf{m m})\end{array}$ & $\begin{array}{c}\text { Average } \\
\text { Dial } \\
\text { Reading }\end{array}$ & $\begin{array}{c}\text { Flow } \\
\text { Value } \\
(\mathbf{m m})\end{array}$ & $\begin{array}{c}\text { Corrected } \\
\text { Flow } \\
\text { Value } \\
(\mathbf{m m})\end{array}$ \\
\hline 0.1 & 405.67 & 4.06 & 3.49 & 611.33 & 6.11 & 5.26 \\
0.2 & 598.33 & 5.98 & 5.15 & 801.67 & 8.02 & 6.89 \\
0.3 & 896.67 & 8.97 & 7.71 & 768.67 & 7.69 & 6.61 \\
0.4 & 1086.67 & 10.87 & 9.35 & 844.67 & 8.45 & 7.26 \\
0.5 & 1070.67 & 10.71 & 9.21 & 697.00 & 6.97 & 5.99 \\
\hline
\end{tabular}

The high flow values obtained is a confirmation of the reinforcing effects of the fibres which makes the asphalt concrete to be stronger and hence have great resistance to plastic deformation (flow). The graphical representation of the flow values of each fibre reinforced asphalt is presented in Figure 14.

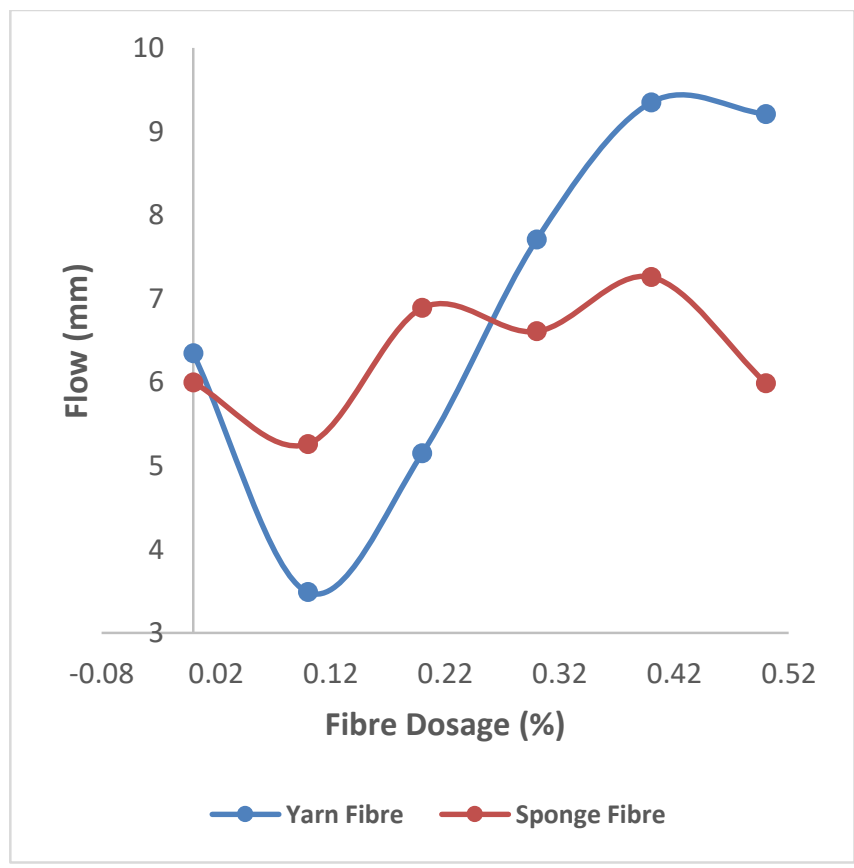

Figure 14: Flow of yarn and sponge gourd.

\section{CONCLUSION}

This research focused on the use of fibres as a reinforcing additive in the production of asphalt concrete and tests were performed to evaluate the properties of the materials used for the production of the asphalt concrete. From the result of tests carried out on asphalt concrete samples, the following conclusions were made. The fibres blend well with other materials when they were introduced into the materials before the application of the binder. The asphalt samples were not well compacted when 50 blows were applied, this is mostly 
noticed with Sisal fibre. However, when the number of blows was increased from 50 to 75 , the asphalt concrete was well compacted, this indicates that more compacting efforts are required for a fibre reinforced asphalt concrete. The highest stability value of $5.54 \mathrm{kN}$ was obtained for Sisal fibre reinforced asphalt concrete was obtained at $0.2 \%$ fibre dosage while the highest stability of $5.99 \mathrm{kN}$ for sponge gourd was obtained at 0.2 fibre dosage. Therefore, $0.2 \%$ fibre dosage of Sisal fibre and sponge gourd gave the optimum performance. The values of flow obtained showed that the flow values were more than the $4 \mathrm{~mm}$ maximum value except for $0.1 \%$ Sisal fibre dosage which has a value of $3.99 \mathrm{~mm}$. The high flow values obtained is an indication of the reinforcing effects of the fibres which makes the asphalt concrete to be stronger and hence have great resistance to plastic deformation (flow).

\section{REFERENCES}

Abtahi S. M.; Sheikhzadeh M. and S. M. (2010). Fibre-reinforced asphalt-concrete - A review. Construction and Building Materials, 24 (6): 871 - 877.

Ali M. (2012). Natural fibres as construction materials. Journal of Civil Engineering and Construction Technology, 3 (3): $80-89$.

Aruna M. (2014). Mechanical Behaviour of Sisal Fibre Reinforced Cement Composites. World Academy of Science, Engineering and Technology International Journal of Materials and Metallurgical Engineering, 8 (4): 650 - 653.

ASTM C128 (2015). Standard Test Method for Relative Density (Specific Gravity) and Absorption of Fine Aggregate, ASTM International, West Conshohocken, PA.

ASTM C566 (2019). Standard Test Method for Total Evaporable Moisture Content of Aggregate by Drying, ASTM International, West Conshohocken, PA.

ASTM D113 (2017). Standard Test Method for Ductility of Asphalt Materials, ASTM International, West Conshohocken, PA, 2017.

ASTM D36 / D36M (2014). Standard Test Method for Softening Point of Bitumen (Ring-and-Ball Apparatus), ASTM International, West Conshohocken, PA, 2014.

ASTM D5 / D5M (2013). Standard Test Method for Penetration of Bituminous Materials, ASTM International, West Conshohocken, PA, 2013

ASTM D6927 (2015). Standard Test Method for Marshall Stability and Flow of Asphalt Mixtures, ASTM International, West Conshohocken, PA, 2013.

ASTM D92 (2016). Standard Test Method for Flash and Fire Points by Cleveland Open Cup Tester, ASTM International, West Conshohocken, PA, 2016.

ASTM D946 / D946M (2020). Standard Specification for Penetration-Graded Asphalt Binder for Use in Pavement Construction, ASTM International, West Conshohocken, PA.

ASTM D95 (2005). Standard Test Method for Water in Petroleum Products and Bituminous Materials by Distillation, ASTM International, West Conshohocken, PA, 2005.

ASTM E8 / E8M (2021). Standard Test Methods for Tension Testing of Metallic Materials, ASTM International, West Conshohocken, PA.
BS 812-103 (1990). Method for determination of particle size distribution: Sedimentation test, British Standards Institution, 389 Chiswick High Road, London.

BS 812-110 (1990). Method for determination of aggregate crushing value (AIV), British Standards Institution, 389 Chiswick High Road, London.

BS 812-112 (1990). Method for determination of aggregate impact value (AIV), British Standards Institution, 389 Chiswick High Road, London.

Dahal R. K.; Acharya B.; Saha G.; Bissessur R.; Dutta A. and Farooque A. (2019). Biochar as a filler in glass fibre reinforced composites: Experimental study of thermal and mechanical properties. Composites Part B: Engineering, 175: 107169.

Fereidoon M. N.; Alireza A.; Gholam H. H. and Hossein R. (2014). Rutting performance prediction of warm mix asphalt containing reclaimed asphalt pavements. Road Materials and Pavement Design, 15 (1): 207 - 219.

Folliard K. J.; Sutfin D.; Turner R. and Whitney D. P. (2006). Fibre in Continuously Reinforced Concrete Pavements. Technical Report, Center for Transportation Research, The University of Texas at Austin, Texas.

Hassan H. J.; Mays F. A. and Israa Y. J. (2011). The Effect of Using Glass Powder Filler on Hot Asphalt Concrete Mixtures Properties. Eng. \& Tech. Journal, 29, (1): $44-57$.

Karahancer S.; Erişkin E.; Saltan M.; Terzi S.; Sarioğlu O. and Küçükçapraz D. O. (2019). Investigating the Utility of Sisal in Hot Mix Asphalt as a Fibre. Journal of Engineering Sciences and Design, 7 (4): 906 - 912.

Lahucik J.; Dahal S.; Roesler J. and Amirkhanian A. (2017). Mechanical properties of roller-compacted concrete with macro-fibres. Construction and Building Materials, 135: 440 - 446.

Mohammad I.; AbuTalib A.; Sultan M. T. H.; Jawai M.; Ariffin A. H. and Saadon S. (2018). Mechanical properties of Fibre-Metal Laminates Made of Natural/Synthetic Fibre composite. BioResources, 13 (1): $2022-2034$.

Naidu V. N. P.; Reddy G. R.; Kumar M. A.; Reddy M. M.; Khanam P. N. and Naidu S. V. (2011). Compressive and impact properties of sisal/glass fibre reinforced hybrid composites. International Journal of Fibre and Textile Research, 1 (1): 11-14.

Naveen K. R.; Manimaran S. and Sureshraja K. (2016). Draindown Analysis of Bituminous Mix Modified with Natural Fibre. International Journal of Innovations in Engineering and Technology, 7 (4): 193 -196.

Okeola A. A.; Abuodha S. O. and Mwero J. (2018). Experimental Investigation of the Physical and Mechanical Properties of Sisal Fibre-Reinforced Concrete. Fibres, 6 (3): 0053.

Oriola F. O. P.; Afolayan J. O.; Sani J. E. and Adamu Y. (2019). Estimating the shear strength of sisal fibre reinforced concrete. Nigerian Journal of Technology, 38 (3): 557- 565

Palit S. K.; Reddy K. S., and Pandey B. B. (2004). Laboratory Evaluation of Crumb Rubber Modified Asphalt Mixes. Journal of Materials in Civil Engineering, 16 (1): 45 53. 
Rahnama E. (2009). A comparison on the performance of styrene-butadiene-styrene (SBS) polymer and textile fibres modifying asphalt concrete. Unpublished MSc Thesis, Iran University of Science and Technology, Iran.

Saranya G.; Naidu M. K. and Rao P. K. (2018). Characterization and Synthesis of Nano Sisal Fibre
Reinforced Composites. International Journal of Engineering Sciences \& Research Technology, 7 (12): 390 - 399.

The Asphalt Institute (1997). Mix Design Methods for Asphalt Concrete and Other Hot-Mix Types (MS-2). The Asphalt Institute, 6th Ed. 